\title{
Utilization of Fatty Acid Methyl Esters for the Differentiation of New Xanthomonas Species
}

\author{
L. VAUTERIN, * P. YANG, AND J. SWINGS \\ Laboratorium voor Microbiologie, Universiteit Gent, B-9000 Ghent, Belgium
}

\begin{abstract}
A database of the fatty acid profiles of the genus Xanthomonas containing the profiles of more than 1,200 authentic xanthomonad strains (P. Yang, L. Vauterin, M. Vancanneyt, J. Swings, and K. Kersters, Syst. Appl. Microbiol. 16:47-71, 1993) was reevaluated to provide data for descriptions and rapid identification of new Xanthomonas species. A total of 1,061 strains in the fatty acid database were grouped into the new species described in the classification of Vauterin et al. (L. Vauterin, B. Hoste, K. Kersters, and J. Swings, Int. J. Syst. Bacteriol. 45:472-489, 1995), and the average fatty acid profiles of the species were determined to obtain a representative fatty acid profile for each species. Within each species, the relative variation in each fatty acid was calculated to determine the potential of fatty acid data for discriminating between species. The fatty acid content of each Xanthomonas species and the relative variation in each fatty acid provide additional data for species descriptions. With the exception of Xanthomonas axonopodis in particular and Xanthomonas arboricola, Xanthomonas hortorum, and Xanthomonas campestris to lesser extents, most Xanthomonas species produce characteristic fatty acid profiles that can be used to differentiate them from other species.
\end{abstract}

The variations in the fatty acids present in bacterial cells have been used for bacterial classification and identification for more than 30 years. Since the introduction of gas chromatographic analysis of cellular fatty acids by Abel et al. (1), this technique has been used frequently in various taxonomic studies (for a review, see reference 19). Workers have described procedures that can be used for rapid characterization of bacteria by fatty acid methyl ester (FAME) analysis and numerical comparison of fatty acid profiles by computer programs (13, 15). FAME analysis has become established in many laboratories involved in taxonomy and diagnostics. In particular, this technique has been used successfully to study phytopathogenic bacteria $(2-7,9-11,14,16-18,23,24)$ and clinical bacteria (for a review, see reference 25 ).

The use of FAME profiles for taxonomic studies of the genus Xanthomonas has been described by Yang et al. (26). These authors have shown that members of the genus Xanthomonas contain at least 65 different fatty acids in significant amounts and that 50 of these fatty acids were present in more than $1 \%$ of the strains when 975 strains were tested. The genus Xanthomonas is characterized by the presence of many branched-chain and hydroxy fatty acids. The great diversity of fatty acids found in this taxon makes FAME analysis a valuable tool for studying relationships within the genus Xanthomonas and, in particular, for rapidly identifying new and unknown strains.

The members of the genus Xanthomonas were recently reclassified into 20 species by Vauterin et al. (20). This reclassification was based on the genomic relationships within the genus as revealed by DNA-DNA hybridization and was largely supported by the results of protein electrophoresis (21) and FAME fingerprinting (26). In order to identify phenotypic characteristics that distinguish the species, the metabolic activities of each species with 95 carbon substrates were determined by using the Biolog GN microplate system (Biolog, Inc., Hayward, Calif.). For most species, the GN microplate assay provided useful data (20). However, some species, such as Xan-

\footnotetext{
* Corresponding author. Mailing address: Laboratorium voor Microbiologie, Universiteit Gent, Ledeganckstraat 35, B-9000 Ghent, Belgium.
}

thomonas axonopodis, Xanthomonas vasicola, Xanthomonas vesicatoria, and Xanthomonas translucens, produced either heterogeneous Biolog profiles or profiles that were not characteristic and thus could not be accurately described in terms of their Biolog profiles. In practicing microbiology laboratories, there is a need for rapid and reproducible phenotypic techniques for identifying bacteria, especially members of genera such as the genus Xanthomonas, which contain many important plant pathogens. FAME analysis has proved to be a rapid and sensitive technique and is reproducible when the experimental conditions are standardized. The fatty acid database established in our laboratory contains data for more than 1,200 genuine Xanthomonas strains and offers great potential for characterization and differentiation of Xanthomonas species.

Because the number of strains that can be clustered on a single dendrogram when the Microbial Identification System software is used is limited, Yang et al. performed a two-step cluster analysis in their fatty acid study of 975 Xanthomonas strains (26). In the first step, each pathovar was clustered separately, and the data for strains belonging to the same pathovar that grouped below a certain level were averaged to obtain a mean profile. The resulting mean profiles were then clustered to produce the final dendrogram. In this study the authors did not attempt to determine fatty acid occurrences or amounts that distinguished strains belonging to different genomic groups within the genus Xanthomonas. In addition, fatty acid profiles were compared and clustered on the basis of Euclidian distances, which implied that the overall fingerprints accounted for the similarities found. The following problems limit the value of FAME fingerprinting when it is combined with clustering for taxonomic purposes: (i) when the Euclidian distance or a related similarity coefficient is used, the major fatty acids (i.e., the fatty acids that occur in large quantities) account for most of the similarity or dissimilarity, whereas the minor fatty acids, which may be as useful for differentiation, have little impact on the overall similarity; and (ii) some fatty acids are informative as taxonomic markers, whereas others vary from strain to strain. Thus, data for taxonomically informative fatty acids may be masked in a cluster analysis based on overall similarity. For these reasons, only the highly characteristic taxa (i.e., the taxa having fatty acids that occurred in major amounts and differentiated them from the other groups) could 
be clearly distinguished on the dendrogram published by Yang et al. (26).

The fact that some Xanthomonas genomic groups could not be identified in a cluster analysis of overall fatty acid profiles does not imply that the method is not suitable for differentiating these groups. In this study, the enormous amount of information in the fatty acid database containing data for more than 1,200 xanthomonad strains was reevaluated to obtain data for rapid identification of new Xanthomonas species by approaches that are suitable for this purpose. Thus, all of the strains in the Xanthomonas fatty acid database generated by us were grouped by species according to the classification proposed by Vauterin et al. (20), and the data were used to determine the average fatty acid profile for each species. Within the species, the variation for each fatty acid was calculated to determine the significance of the average amounts. The descriptions of the species in terms of their fatty acid contents provide additional data for the current species descriptions. The fatty acid data were used to distinguish the species at a certain level of significance, which allowed us to identify new and unknown xanthomonads on the basis of their fatty acid profiles.

\section{MATERIALS AND METHODS}

Bacterial strains. A total of 1,061 strains belonging to the Xanthomonas species described by Vauterin et al. (20) were selected on the basis of the results of a fingerprint analysis of more than 1,200 strains in which sodium dodecy sulfate-polyacrylamide gel electrophoresis of proteins and FAME profiles were used, as described previously $(21-24,26)$. These strains were identified as authentic xanthomonads by their Xanthomonas-specific protein patterns and fatty acids $(21,26$; this study). All of the strains listed below were obtained from the culture collection of the Laboratorium voor Microbiologie, Universiteit Gent, Ghent, Belgium.

Xanthomonas albilineans strains. The following $X$. albilineans strains were used LMG 477, LMG 480, LMG 481, LMG 482, LMG 483, LMG 484, LMG 485, LMG 487, LMG 488, LMG 489, LMG 490, LMG 491, LMG 492, LMG 494 (T = type strain), LMG 12025, LMG 12026, LMG 12027, LMG 12028, LMG 12029, LMG 12030, LMG 12031, LMG 12032, LMG 12033, LMG 12034, LMG 12035, LMG 12036, LMG 12037, LMG 12038, LMG 12039, LMG 12040, LMG 12041, LMG 12042, LMG 12043, LMG 12044, LMG 12045, LMG 12046, LMG 12047, LMG 12048, LMG 12049, LMG 12050, LMG 12051, LMG 12052, LMG 12053, LMG 12054, LMG 12055, LMG 12056, LMG 12057. LMG 12058, LMG 12059, LMG 12060, LMG 12061, LMG 12062, LMG 12064, LMG 12067, LMG 12068, LMG 12070, LMG 12072, LMG 12073, LMG 12074, LMG 12075, LMG 12076, LMG 12077, LMG 12078, LMG 12079, LMG 12080, and LMG 12081.

Xanthomonas arboricola strains. The following $X$. arboricola strains were used $X$. arboricola pv. corylina LMG 688, LMG 689 (pathovar reference strain), LMG 7395, LMG 8658, LMG 8659, and LMG 8660; $X$ arboricola pv. juglandis LMG 746, LMG $747^{\mathrm{T}}$, LMG 748, LMG 749, LMG 750, LMG 751, LMG 752, LMG 8045, LMG 8046, LMG 8047, LMG 12703, and LMG 12704; $X$ arboricola pv. populi LMG 2984, LMG 12122, LMG 12123, LMG 12124, LMG 12125, LMG 12126, LMG 12127, LMG 12128, LMG 12129, LMG 12130, LMG 12131, LMG 12132, LMG 12133, LMG 12134, LMG 12135, LMG 12136, LMG 12137, LMG 12138, LMG 12139 , LMG 12141 (pathovar reference strain), LMG 12142, LMG 12143, LMG 12144, LMG 12145, LMG 12146, LMG 12147, LMG 12148, LMG 12469, LMG 12470, LMG 12471, LMG 12472, LMG 12473, LMG 12474, LMG 12476, LMG 12477, LMG 12478, LMG 12479, LMG 12480, LMG 12481, LMG 12482, LMG 12483, LMG 12484, and LMG 12485: $X$ arboricola pv. pruni LMG 850, LMG 851, LMG 852 (pathovar reference strain), LMG 853, LMG 854, LMG 855, LMG 856, LMG 857, LMG 858, LMG 7437, LMG 7438, LMG 8679, LMG 8680, and LMG 8681; and four $X$. arboricola strains formerly classified as $X$. campestris pv. poinsettiicola type C strains (20) (strains LMG 5402, LMG 5403, LMG 8675, and LMG 8676).

Xanthomonas axonopodis strains. The following $X$. axonopodis strains were used: $X$. axonopodis pv, alfalfae LMG 495, LMG 496, LMG 497 (pathovar reference strain), LMG 8018, LMG 8019, LMG 8020, LMG 8078, LMG 8079, LMG 8080, LMG 9328, LMG 9329, and LMG 9330; $X$. axonopodis pv. axonopodis LMG 538 ${ }^{\mathrm{T}}$, LMG 539, and LMG 540; $X$. axonopodis pv. begoniae LMG 550 LMG 551, LMG 552, LMG 553, LMG 7178, LMG 7188, LMG 7189, LMG 7190, LMG 7193, LMG 7194, LMG 7195, LMG 7196, LMG 7226, LMG 7227, LMG 7303 (pathovar reference strain), LMG 7304, LMG 7306, LMG 7307, LMG 7589, LMG 7590, LMG 7591, LMG 7592, LMG 7593, LMG 7594, LMG 7595, LMG 7596, LMG 7597, LMG 7598, LMG 7599, LMG 7600, LMG 7601, and LMG $7617 ; X$ axonopodis pv. cajani LMG 558 (pathovar reference strain), LMG 7387 and LMG 7473; $X$. axonopodis pv. cassavae LMG 8048, LMG 8049, and LMG
8237; $X$, axonopodis pv. citri type A (8) strains LMG 680. LMG 681, LMG 682 (pathovar reference strain), LMG 683, LMG 8650, LMG 8651, LMG 8652, LMG 8654, LMG 8655, LMG 8657, LMG 9176, LMG 9177, LMG 9178, LMG 9321, LMG 9322, LMG 9652, LMG 9653, LMG 9656, LMG 9657, LMG 9659, LMG 9660, LMG 9661, LMG 9662, LMG 9663, LMG 9664, LMG 9666, LMG 9667, LMG 9668, LMG 9669, LMG 9670, and LMG 9672; X. axonopodis pv. citri type B (8) strains LMG 9179, LMG 9183, and LMG 9185; X. axonopodis pv. citri type C (8) strains LMG 8655, LMG 8656, LMG 9181, LMG 9654, and LMG 9658; $X$. axonopodis pv. citri type D (8) strain LMG 9182; $X$. axonopodis pv. citri type E (8) strains LMG 9161, LMG 9162, LMG 9163, LMG 9165, LMG 9166, LMG 9167, LMG 9168, LMG 9169, LMG 9170, LMG 9171, LMG 9172, LMG 9173, LMG 9174, LMG 9175, LMG 9323, LMG 9324, LMG 9325, LMG 9326, LMG 9327, and LMG 9331; $X$. axonopodis pv. coracanae LMG 686 (pathovar reference strain) and LMG 7476; $X$. axonopodis pv. cyamopsidis LMG 691 (pathovar reference strain), LMG 7398, LMG 7482, and LMG 7483; $X$. axonopodis pv. desmodiigangetici LMG 693 (pathovar reference strain); $X$. axonopodis pv. dieffenbachiae LMG 695 (pathovar reference strain), LMG 7399, LMG 7400, LMG 7484, LMG 8664, LMG 12708, LMG 12709, LMG 12710, LMG 12711, LMG 12712, LMG 12713, LMG 12714, LMG 12715, LMG 12716, LMG 12717, LMG 12718, LMG 12719, LMG 12720, LMG 12721, LMG 12722, LMG 12723, LMG 12724, LMG 12725, LMG 12726, LMG 12727, LMG 12728, LMG 12729, LMG 12730, LMG 12731, LMG 12732, LMG 12733, LMG 12734, LMG 12735, LMG 12736, LMG 12737, LMG 12738, LMG 12739, LMG 12740, LMG 12741, LMG 12742, LMG 12743, LMG 12744, LMG 12745, LMG 12746, LMG 12747, LMG 12748, LMG 12749, LMG 12750, LMG 12751, LMG 12752, LMG 12894, and LMG 12895; $X$. axonopodis pv. erythrinae LMG 698 (pathovar reference strain) and LMG 7486; $X$. axonopodis pv. glycines LMG 712 (pathovar reference strain), LMG 7403, LMG 7404, LMG 7487, LMG 7488, LMG 8023, LMG 8024, LMG 8025, LMG 8026, LMG 8027, LMG 8124, LMG 8126, LMG 8127, LMG 8128, LMG 10408, LMG 10409, LMG 10410, and LMG 10411; $X$. axonopodis pv. malvacearum LMG 759, LMG 760, LMG 761 (pathovar reference strain), LMG 762, LMG 763, LMG 764, LMG 7426, LMG 7427, LMG 7428, LMG 7429, LMG 9570. LMG 9571, LMG 9572, LMG 9573, LMG 9574, LMG 10412, LMG 10413, LMG 10414, LMG 10415, LMG 10420, LMG 10421, LMG 10422, LMG 10423, LMG 10424, LMG 11167, LMG 11168, LMG 11169, LMG 11170, LMG 11171 , LMG 11172, LMG 11173, LMG 11174, LMG 11175, LMG 11176, LMG 11202 LMG 11203, LMG 11204, LMG 11205, LMG 11378, LMG 11379, LMG 11380 LMG 11381, LMG 11382, LMG 11383, LMG 11725, LMG 11726, LMG 11727, LMG 11728, LMG 11729, LMG 11730, LMG 11780, LMG 11781, LMG 11782 LMG 11784, LMG 11785, LMG 11786, LMG 11787, LMG 11788, LMG 11789 , LMG 11790, LMG 11791, LMG 11792, LMG 11793, LMG 11794, LMG 12811, LMG 12812, LMG 12813, LMG 12817, LMG 12818, LMG 12819, LMG 12820, LMG 12821, LMG 12822, LMG 12823, LMG 12824, LMG 12825, LMG 12826, LMG 12828, and LMG 12829; $X$. axonopodis pv. manihotis LMG 629, LMG 765 , LMG 766, LMG 767, LMG 769, LMG 770, LMG 771, LMG 772, LMG 773 (pathovar reference strain), LMG 774, LMG 775, LMG 776, LMG 777, LMG 778, LMG 780, LMG 781, LMG 782, LMG 783, LMG 5245, LMG 5247, LMG 5248, LMG 5249, LMG 5250, LMG 5273, LMG 5287, and LMG 5288; $X$. axonopodis pv. patelii LMG 811 (pathovar reference strain) and LMG 7500; $X$ axonopodis pv. phaseoli LMG 821, LMG 822, LMG 823, LMG 829, LMG 830, LMG 833, LMG 834, LMG 836, LMG 842, LMG 7455 (pathovar reference strain), LMG 8011, LMG 8012, LMG 8013, LMG 8014, LMG 8015, LMG 10425, and LMG 10426; $X$ axonopodis pv. phaseoli 'fuscans' strains LMG 666. LMG 824, LMG 825, LMG 826, LMG 827, LMG 832, LMG 837, LMG 838, LMG 841, LMG 7456, LMG 7457, LMG 7458, LMG 7459, LMG 7511, LMG 7512, LMG 8016, LMG 8017, LMG 8036, LMG 8037, LMG 8038, LMG 8039. LMG 8040, LMG 10427, and LMG 10428; $X$. axonopodis pv. phyllanthi LMG 844 (pathovar reference stain); $X$. axonopodis pv. poinsettiicola LMG 849 (pathovar reference strain) and LMG 5401; $X$ axonopodis pv. ricini LMG 861 (pathovar reference strain:, LMG 864, LMG 7440, LMG 7441, LMG 7442, LMG 7443, LMG 7444, LMG 86.62 , and LMG 8683; $X$. axonopodis pv. sesbaniae LMG 867 (pathovar reference strain) and LMG 7447; $X$. axonopodis pv. vasculorum LMG 894, LMG 895, LMG 897, LMG 898, LMG 899, LMG 901 (pathovar reference strain), LMG 903, LMG 8709, LMG 8712, LMG 8713, LMG 8715, LMG 8716, LMG 8741, LMG 8743, LMG 8745, and LMG 9721; $X$. axonopodis pv. vignicola LMG 828, LMG 831, LMG 839, LMG 840, LMG 8136, LMG 8137, LMG 8138, LMG 8139, LMG 8140, LMG 8752 (pathovar reference strain), LMG 10430, LMG 10431, and LMG 10432; and $16 X$. axonopodis strains formerly classified as $X$. campestris pv, vesicatoria type A strains (20-22) (strains LMG 667, LMG 668, LMG 904, LMG 905, LMG 906, LMG 909, LMG 913, LMG 914, LMG 922 LMG 926, LMG 929, LMG 930, LMG 931, LMG 932, LMG 933, and LMG 12696).

Xanthomonas bromi strains. The following $X$. bromi strains were used: LMG 947 T. LMG 8267, LMG 8268, LMG 8269, LMG 8270, LMG 8271, LMG 8272 and LMG 8273.

Xanthomonas campestris strains. The following $X$. campestris strains were used: $X$. campestris pv. aberrans LMG 8038, LMG 9037 (pathovar reference strain), and LMG 9039; $X$ campestris pv, armoraciae LMG 498, LMG 499, LMG 535 (pathovar reference strain), LMG 7383, and LMG 7468; $X$. campestris pv, barbareae LMG 547 (pathovar reference strain), LMG 7385, and LMG 7471; $X$. campestris pv. campestris LMG 565, LMG 566, LMG 567, LMG 568 ${ }^{\mathrm{T}}$, LMG 569, LMG 570, LMG 571, LMG 572, LMG 573, LMG 574, LMG 575, LMG 581, 
LMG 582, LMG 583, LMG 584, LMG 7460, LMG 7461, LMG 7514, LMG 7515 , LMG 7516, LMG 7662, LMG 7663, LMG 8001, LMG 8003, LMG 8005, LMG 8006, LMG 8007, LMG 8008, LMG 8009, LMG 8031, LMG 8032, LMG 8034, LMG 8035, LMG 8050, LMG 8051, LMG 8054, LMG 8055, LMG 8060, LMG 8062, LMG 8082, LMG 8085, LMG 8086, LMG 8087, LMG 8088, LMG 8089, LMG 8091, LMG 8092, LMG 8093, LMG 8094, LMG 8095, LMG 8096, LMG 8098, LMG 8099, LMG 8100, LMG 8102, LMG 8112, LMG 8118, LMG 8119 , LMG 8120, LMG 8121, and LMG 8123; $X$. campestris pv. incanae LMG 7421, LMG 7422, LMG 7490 (pathovar reference strain), and LMG 8669; and $X$ campestris pv. raphani LMG 860 (pathovar reference strain), LMG 7505, LMG 7506, LMG 8010, LMG 8134, and LMG 8135.

Xanthomonas cassavae strains. The following $X$. cassavae strains were used LMG 670, LMG 671, LMG 672, LMG 673 ${ }^{\mathrm{T}}$, LMG 674, LMG 5246, LMG 5264 LMG 5265, LMG 5266, LMG 5267, LMG 5268, LMG 5269, LMG 5270, and LMG 5271.

Xanthomonas codiae strains. The following $X$. codiaei strains were used: LMG 8677 and LMG $8678^{\mathrm{T}}$.

Xanthomonas cucurbitae strains. The following $X$. cucurbitae strains were used LMG 690 ${ }^{\mathrm{T}}$, LMG 7479, LMG 7480, LMG 7481, LMG 8661, LMG 8662, and LMG 8663.

Xanthomonas fragariae strains. The following $X$. fragariae strains were used: LMG 703, LMG 704, LMG 705, LMG 706, LMG 707, LMG 708 ${ }^{\mathrm{T}}$, LMG 709,

LMG 710, and LMG 12702.

Xanthomonas hortorum strains. The following $X$. hortorum strains were used: $X$. hortorum pv. hederae LMG 733. ${ }^{\mathrm{T}}$, LMG 734, LMG 7410, LMG 7411, LMG 7412 LMG 7413, LMG 7414, LMG 8665, LMG 8666, LMG 8667, LMG 8668, and LMG 9578; $X$. hortorum pv. pelargonii LMG 819, LMG 820, LMG 7179, LMG 7180, LMG 7191. LMG 7228, LMG 7309, LMG 7310. LMG 7311, LMG 7312 LMG 7314 (pathovar reference strain), LMG 7315, LMG 7316, LMG 7317 LMG 7318, LMG 7353, LMG 7354, LMG 7355, LMG 7356, LMG 7585, LMG 7619, LMG 7666, LMG 7673, LMG 7689, LMG 7690, LMG 7692, LMG 7696 LMG 7697, LMG 7698, LMG 7704, LMG 7705, LMG 7706, LMG 7707, LMG 7708, LMG 7709, LMG 7710, LMG 7712, LMG 7713, LMG 7714, LMG 7715 LMG 7716, LMG 7717, LMG 7718, LMG 7719, LMG 7720, LMG 7721, LMG 7762, LMG 7763, LMG 7764, LMG 7765, LMG 7766, LMG 7767, LMG 7768 LMG 7769, LMG 7770, LMG 7775, LMG 7778, LMG 7783, and LMG 7784; and $X$. hortorum pv. vitians LMG 938, LMG 7452, LMG 7453, LMG 7508, LMG 7509, LMG 7510, LMG 8687, LMG 8688, and LMG 8690.

Xanthomonas hyacinthi strains. The following $X$. hyacinthi strains were used LMG 628, LMG 739 , LMG 740, LMG 741, LMG 742, LMG 7419, LMG 7420 LMG 8041, LMG 8042, LMG 8043, and LMG 8044.

Xanthomonas melonis strains. The following $X$. melonis strains were used: LMG 8670, LMG 8671, LMG 8672, LMG 8673, and LMG 8674.

Xanthomonas oryzae strains. The following $X$. oryzae strains were used: $X$ oryzae pv. oryzae LMG 630, LMG 631, LMG 632, LMG 634, LMG 635, LMG 636, LMG 637, LMG 638, LMG 639, LMG 640, LMG 641, LMG 642, LMG 643 LMG 645, LMG 646, LMG 647, LMG 648, LMG 649, LMG 650, LMG 788, LMG 789, LMG 790, LMG 791, LMG 794, LMG 795, LMG 796, LMG 799, LMG 800, LMG 801, LMG 802, LMG 803, LMG 804, LMG 805, LMG 806 LMG $5047^{\mathrm{T}}$, LMG 6518, LMG 9010, LMG 9011, LMG 9012, LMG 9013, LMG 9596, LMG 9601, LMG 9602, LMG 9603, LMG 9604, LMG 9605, LMG 9606 LMG 9607, LMG 9608, LMG 9609, LMG 9610, LMG 9611, LMG 9612, LMG 9613, LMG 9614, LMG 9615, LMG 9616, LMG 9617, LMG 9618, LMG 9619, LMG 9620, LMG 9621, LMG 9622, LMG 9623, and LMG 9624; and X. oryzae pv. oryzicola LMG 654, LMG 655, LMG 656, LMG 657, LMG 658, LMG 660, LMG 661, LMG 662, LMG 663, LMG 665, LMG 792, LMG 793, LMG 797 (pathovar reference strain), LMG 798, LMG 9644, LMG 9645, LMG 9646, LMG 9647, LMG 9648, LMG 9649, LMG 9650, LMG 9651, LMG 9717, LMG 9718, LMG 9719, LMG 9720, LMG 9721, LMG 9722, and LMG 9723.

Xanthomonas pisi strain. The following $X$. pisi strain was used: LMG $847^{\mathrm{T}}$

Xanthomonas populi strains. The following $X$. populi strains were used: LMG 971, LMG 974, LMG 5743 T. LMG 5745, LMG 5746, LMG 5747, LMG 5749 LMG 5751, LMG 5752, LMG 5755, LMG 5758, LMG 5759, LMG 5760, LMG 5761, LMG 5762, LMG 5763, LMG 5764, LMG 5765, LMG 5767, LMG 5770 LMG 5771, LMG 5772, LMG 5773, LMG 5775, LMG 5777, LMG 5778, LMG 5779, LMG 5780, LMG 5781, LMG 5782, LMG 5783, LMG 5784, LMG 5785 LMG 5787, LMG 5788, LMG 5789, LMG 5791, LMG 5792, LMG 5793, LMG 5794, LMG 5795, LMG 6579, LMG 6580, LMG 6581, LMG 7518, LMG 7519 LMG 7520, LMG 7521, LMG 7722, LMG 7723, LMG 7724, LMG 7725, LMG 7726, LMG 7727, LMG 7728, LMG 7729, LMG 7730, LMG 7731, LMG 7732 LMG 7733, LMG 7735, LMG 7736, LMG 7738, LMG 7739, LMG 7740, LMG 7741, LMG 7742, LMG 7745, LMG 7747, LMG 7748, LMG 7749, LMG 7750 LMG 7753, LMG 7754, and LMG 7755.

Xanthomonas sacchari strains. The following $X$ sacchari strains were used LMG 471 ${ }^{\mathrm{T}}$, LMG 472, LMG 473, LMG 474, LMG 475, and LMG 476.

Xanthomonas theicola strains. The following $X$. theicola strains were used: LMG $8684^{\mathrm{T}}$, LMG 8685 , and LMG 8686

Xanthomonas translucens strains. The following $X$. translucens strains were used: $X$. translucens pv. arrhenatheri LMG 588, LMG 590, LMG 591, LMG 592 , LMG 727 (pathovar reference strain), and LMG 7384; X. translucens pv. cerealis LMG 679 (pathovar reference strain), LMG 880, LMG 881, LMG 887, LMG 890, LMG 891, LMG 7392, and LMG 7393; $X$. translucens pv. graminis LMG 587,
LMG 589, LMG 595, LMG 596, LMG 597, LMG 599, LMG 600, LMG 601, LMG 602, LMG 603, LMG 604, LMG 605, LMG 606, LMG 607, LMG 608 LMG 609, LMG 610, LMG 611, LMG 612, LMG 613, LMG 614, LMG 615 , LMG 616, LMG 617, LMG 618, LMG 619, LMG 620, LMG 621, LMG 622 LMG 623, LMG 624, LMG 625, LMG 626, LMG 713, LMG 714, LMG 715 LMG 721, LMG 722, LMG 726 (pathovar reference strain), LMG 729, LMG 7405, LMG 7406, LMG 7407, and LMG 7408; X. translucens pv. hordei LMG 737 (pathovar reference strain), LMG 879, LMG 882, LMG 884, LMG 889, LMG 8278, LMG 8279, LMG 8280, and LMG 8281; $X$. transtucens pv. phlei LMG 716 , LMG 717, LMG 718, LMG 719, LMG 720, LMG 723, and LMG 730 (pathova reference strain); $X$. translucens pv, secalis LMG 877 , LMG 883 (pathovar reference strain), LMG 7445, and LMG 7507; $X$. translucens pv. translucens LMG

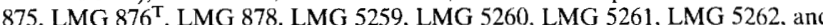
LMG 5263; and $X$. translucens pv. undulosa LMG 885, LMG 886. LMG 888 , LMG 892 (pathovar reference strain), LMG 8282, and LMG 8283.

Xanthomonas vasicola strains. The following $X$. vasicola strains were used: $X$. vasicola pv. holcicola LMG 736 ${ }^{\mathrm{T}}$, LMG 7416, LMG 7417, LMG 7418, LMG 7489 LMG 8276, LMG 8277, and LMG 8707; and $12 X$. vasicola strains formerly classified as $X$. campestris pv. vasculorum strains (strains LMG 900, LMG 902 LMG 8284, LMG 8710, LMG 8711, LMG 8714, LMG 8717, LMG 8718, LMG 8719, LMG 8720, LMG 8742, and LMG 8744).

Xanthomonas vesicatoria strains. The following $X$ vesicatoria strains were used: LMG 911 ${ }^{\mathrm{T}}$, LMG 917, LMG 919, LMG 920, LMG 923, LMG 924, and LMG 925. Gas chromatographic analysis of FAMEs. Bacterial strains were precultured for 3 days on nutrient agar slants $(0.1 \%$ [wt/vol] Lab Lemco, $0.2 \%$ [wt/vol] yeas extract, $0.5 \%$ [wt/vol] $\mathrm{NaCl}, 2.0 \%$ [wt/vol] agar). The precultures were streaked onto TSA plates $(3.0 \%$ [wt/vol] Trypticase soy broth [BBL], $1.5 \%$ [wt/vol] Bacto Agar [Difco]) in four quadrants, and most plates were incubated at $28^{\circ} \mathrm{C}$ for 48 h. $X$. populi strains were incubated at $19^{\circ} \mathrm{C}$ since this species does not grow a temperatures above $22^{\circ} \mathrm{C}$. A loopful of cells from the zone where the second and third quadrants overlapped on each plate was harvested with a sterile $10-\mu$ plastic loop. These cells (approximately $50 \mathrm{mg}$ ) were inoculated into a test tube capped with a Teflon-lined screw cap. FAMEs were prepared and extracted from the bacterial cells by using the procedure described by Stead (16).

A model 5890A gas-liquid chromatograph (Hewlett-Packard Co., Avondale, Pa.) was used to separate the FAMEs on a fused silica capillary column $(25 \mathrm{~m}$ by $0.2 \mathrm{~mm}$ ) coated with methyl phenyl silicone (Hewlett-Packard). The parameters used with the instrument were those described by Korn-Wendisch et al. (12) Fatty acids were identified and quantified by using the Microbial Identification (MIDI) System software (version 3.8; Microbial ID, Inc., Newark, Del.). The relative amount of each fatty acid in a strain was expressed as a percentage of the total fatty acids in the FAME profile of that strain. Samples for which the total profile area was less than 75,000 were prepared a second time, as recommended by the manufacturer of the Microbial Identification System.

The fatty acid profiles of the 1,061 strains used in this study were imported into the GelCompar software (version 3.1; Applied Maths BVBA, Kortrijk, Belgium). Strains classified as Xanthomonas sp. (20) were not included. The strains were grouped by species by using the classification of Vauterin et al. (20), and for each species the average percentages of occurrence and corresponding standard deviations were calculated for all of the fatty acids found. Only those fatty acids for which the amount minus the standard deviation was greater than zero in at least one species were used in our analysis. The relative amounts of a fatty acid were considered data which could be used to distinguish two species when the lower amount plus its standard deviation was less than the higher amount minus its standard deviation.

\section{RESULTS AND DISCUSSION}

When we used an incubation time of $24 \mathrm{~h}$ as recommended by the manufacturer of Microbial Identification System. not all Xanthomonas species and pathovars produced enough growth to yield reliable fatty acid profiles. The species that grew particularly slowly were $X$. hyacinthi, $X$. theicola, $X$. oryzae, $X$. fragariae, $X$. populi, and $X$. albilineans. After $24 \mathrm{~h}$ of incubation, most xanthomonad cultures were in the early logarithmic or logarithmic growth phase. Depending on the taxon studied, fatty acid composition may be very sensitive to the age of the cells, and the early logarithmic growth phase has been found in many cases to be the least reliable growth phase for obtaining stable and reproducible profiles. On the basis of the results of repeated experiments in which incubation times of 24 and $48 \mathrm{~h}$ were used, it was found that xanthomonads exhibited less variation in their fatty acid profiles when they were incubated for $48 \mathrm{~h}(16,26)$. In addition, this longer incubation time was necessary to obtain enough cells of the slowly growing species mentioned above. Therefore, all of the strains used to produce the Xanthomonas database were incubated for $48 \mathrm{~h}$. 
The reproducibility of the technique was monitored by preparing duplicate FAME extracts for more than 250 strains. We found that the variations in individual fatty acid concentrations were generally less than $3 \%$ for the most abundant fatty acids (26), which proved that the standardized procedure which we used was reproducible enough for its intended purpose.

In order to characterize the Xanthomonas species on the basis of their fatty acid compositions, we calculated the levels of all fatty acids for the strains belonging to each species. Table 1 shows the average fatty acid compositions of all Xanthomonas species, as well as the standard deviation of each fatty acid present. Fatty acids for which the amount minus the standard deviation was less than zero in all species were not considered further and are not listed in Table 1.

In general, the average levels of fatty acids were based on data obtained for numerous strains and may be considered representative within the bounds of the standard deviations. For example, in $X$. axonopodis the values were the average values obtained for 400 strains, and the average profiles for $X$. arboricola, $X$. campestris, $X$. hortorum, $X$. oryzae, $X$. populi, and $X$ translucens were all based on data obtained for more than 70 strains per species. However, only two strains of $X$. codiaei, three strains of $X$. theicola, and one strain of $X$. pisi were available; it is obvious that the levels of fatty acids, as well as the standard deviations, were not firmly defined for these species.

Species that exhibited little variation in their fatty acid profiles were more accurately defined than species that exhibited large variations. In order to obtain an idea of the consistency of the overall profiles within each species, the internal homogeneity $(h)$ was calculated by using the following formula:

$$
h=1-\sum_{i=1}^{n} \sum_{j=1}^{m} \frac{\left|\bar{x}_{i}-x_{i, j}\right|}{n m \bar{x}_{i}}
$$

where

$$
\bar{x}_{i}=\sum_{j=1}^{m} \frac{x_{i, j}}{m}
$$

where $n$ is the total number of fatty acids considered and $m$ is the number of strains of the species. Thus, $x_{i, j}$ is the percentage of the $i$ th fatty acid in the $j$ th strain of the species and $\bar{x}_{i}$ is the average percentage of the $i$ th fatty acid in the species. The resulting values are shown in Table 2 . Among the least homogeneous species were $X$. populi, $X$. translucens, and particularly $X$. axonopodis. The heterogeneity found for $X$. axonopodis was based on 400 strains and thus clearly reflects the genomic diversity of this group (20). $X$. populi, however, is a homogeneous taxon genomically and on the basis of protein electrophoretic profiles (20; unpublished data), and the apparent heterogeneity of this species may be due to the poor and variable growth of the cultures rather than significant differences in fatty acid contents. A similar heterogeneity was found for $X$. populi when the species was characterized by using Biolog GN microplates (20). $X$. translucens is another species that contains several pathovars, and thus the heterogeneity of this taxon can be explained by the fact that the pathogenic groups that make up this species differ in their fatty acid profiles. This was clearly shown in the study of Yang et al. (26), who found that all former $X$. campestris pathovars now classified in $X$. translucens belonged to three groups; the first of these groups contained $X$. translucens pv. poae, $X$. translucens pv. graminis, and $X$. translucens pv. phleipratensis, the second contained $X$. translucens pv. arrhenatheri and $X$. translucens pv. phlei, and the third contained the pathovars from cereals ( $X$. translucens pv. hordei, $X$. translucens pv. cerealis, $X$. translucens pv. undulosa, $X$. translucens pv. translucens, and $X$. translucens pv. secalis). However, other species composed of pathovars from different, even unrelated hosts, such as $X$. arboricola and $X$. hortorum, are much more homogeneous in terms of their fatty acid contents, sometimes even compared with single-host species, such as $X$. albilineans and $X$. oryzae.

The species could not be distinguished reliably on the basis of the presence or absence of fatty acids (i.e., by qualitative differences). In most cases, fatty acids that were not present in some species were present only in minor amounts in the other species. Therefore, it was necessary to differentiate the species by quantitative differences in their fatty acids. When the number of strains of a taxon is large enough, the distribution of the amounts of each fatty acid within the taxon is expected to be Gaussian. Therefore, we based our species differentiation on the standard deviation of the distribution. The amounts of fatty acids were considered data that could be used to distinguish two species when the lower amount plus its standard deviation was less than the higher amount minus its standard deviation. The number of fatty acids that could be used to distinguish two species and the significance of the discrimination varied with the species considered. Listing the fatty acids that differentiate all possible pairs of species would require 190 tables, which would be impossible to present in this paper. Therefore, in order to present an idea of the levels of discrimination between all of the pairs of species, Table 2 shows the total numbers of discriminating fatty acids. It appeared that there were no fatty acids that fulfilled the criteria used for differentiation in only two cases $(X$. axonopodis and $X$. arboricola; $X$ axonopodis and $X$. campestris). All of the other species pairs differed significantly, with the number of different fatty acids ranging from 1 to 36 (for $X$. populi and $X$. sacchari).

The unicity of each species was estimated by adding the numbers of fatty acids that could be used to differentiate the species all of the other species. The unicity values are shown in Table 2 . These values clearly show that the fatty acid profiles of some species are more characteristic than the fatty acid profiles of other species. The species with the most unusual profiles were $X$. albilineans, $X$. codiaei, $X$. hyacinthi, $X$. pisi, $X$. populi, $X$. sacchari, and $X$. theicola. The unicity of the $X$. pisi profile should be interpreted with caution, as the amounts of the fatty acids were based on a single strain, which implies that the standard deviation for this profile is zero for all fatty acids. $X$. axonopodis had by far the lowest number of discriminating fatty acids, a result which was expected because of the heterogeneity of this species as determined by DNA-DNA hybridization and other phenotypic traits (20). Other less well-defined species include $X$. arboricola, $X$. campestris, $X$. hortorum, and $X$. translucens. Interestingly, all of these species are composed of different pathovars, and thus we thought that the rather poor characterization of these species could be related to their heterogeneity. As discussed above, this is only true for $X$. axonopodis and $X$. translucens. In contrast, $X$. campestris, which contains six pathovars isolated from members of the Brassicaceae, is a relatively homogeneous species (level of homogeneity, $80.3 \%$ ) (Table 2). Thus, the low unicity value for this species was explained by the fact that it contains few fatty acids that can be used to differentiate it from the other species.

In conclusion, our results show that most Xanthomonas species produce characteristic fatty acid profiles and that the fatty acid profile technique is a suitable method for identifying Xanthomonas taxa at least up to the species level. Although it is unlikely that a single technique will ever allow workers to identify any new xanthomonad unambiguously, we believe that 


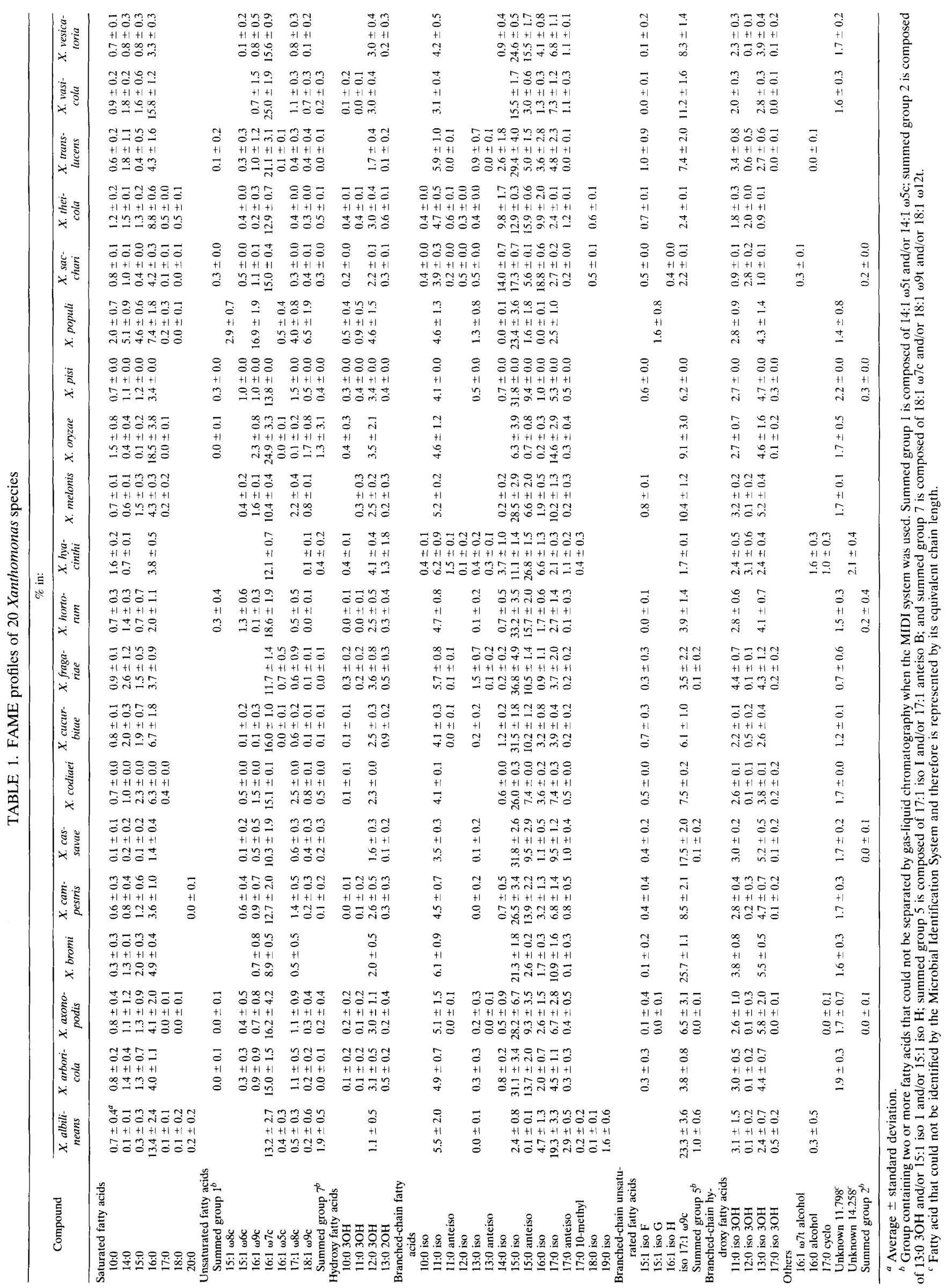


TABLE 2. Variations in fatty acid profiles within and between Xanthomonas species

\begin{tabular}{|c|c|c|c|c|c|c|c|c|c|c|c|c|c|c|c|c|c|c|c|c|c|c|}
\hline \multirow[b]{2}{*}{ Species } & \multirow[b]{2}{*}{$\begin{array}{l}\text { No. of } \\
\text { strains } \\
\text { used }\end{array}$} & \multirow[b]{2}{*}{$\begin{array}{l}\text { Internal } \\
\text { homo- } \\
\text { geneity }\end{array}$} & \multirow[b]{2}{*}{$\begin{array}{l}\text { Total no. of } \\
\text { differentiating } \\
\text { fatty acids }{ }^{a}\end{array}$} & \multicolumn{19}{|c|}{ No. of differentiating fatty acids } \\
\hline & & & & 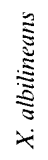 & 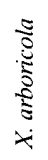 & 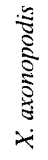 & 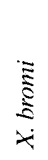 & 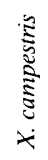 & 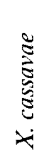 & 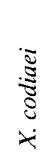 & ن & 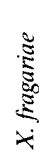 & 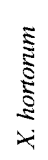 & 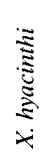 & 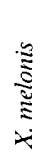 & 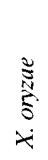 & $\frac{\bar{\Xi}}{\dot{\Sigma}}$ & $\underset{\grave{\Xi}}{\grave{\Xi}}$ & 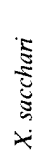 & 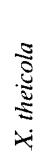 & 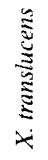 & $\frac{\mathfrak{s}}{3}$ \\
\hline$X$. albilineans & 66 & 0.75 & 395 & & & & & & & & & & & & & & & & & & & \\
\hline$X$ arboricola & 79 & 0.79 & 228 & 20 & & & & & & & & & & & & & & & & & & \\
\hline$X$ axonopodis & 400 & 0.44 & 135 & 15 & 0 & & & & & & & & & & & & & & & & & \\
\hline$X$. bromi & 8 & 0.94 & 309 & 17 & 10 & 3 & & & & & & & & & & & & & & & & \\
\hline$X$. campestris & 82 & 0.80 & 209 & 18 & 1 & 0 & 8 & & & & & & & & & & & & & & & \\
\hline$X$. cassavae & 14 & 0.85 & 308 & 16 & 12 & 4 & 9 & 9 & & & & & & & & & & & & & & \\
\hline$X$. codiaei & 2 & 0.97 & 383 & 22 & 15 & 7 & 22 & 10 & 22 & & & & & & & & & & & & & \\
\hline X. cucurbitae & 7 & 0.88 & 303 & 20 & 6 & 2 & 16 & 9 & 17 & 20 & & & & & & & & & & & & \\
\hline$X$. fragariae & 9 & 0.79 & 283 & 18 & 7 & 3 & 13 & 9 & 14 & 25 & 11 & & & & & & & & & & & \\
\hline$X$. hortorum & 80 & 0.78 & 243 & 20 & 2 & 1 & 10 & 3 & 12 & 17 & 8 & 6 & & & & & & & & & & \\
\hline$X$. hyacinthi & 11 & 0.92 & 498 & 27 & 24 & 19 & 28 & 25 & 24 & 32 & 26 & 21 & 25 & & & & & & & & & \\
\hline$X$. oryzae & 94 & 0.76 & 291 & 11 & 14 & 9 & 12 & 12 & 13 & 17 & 16 & 16 & 12 & 21 & 12 & & & & & & & \\
\hline$X . p i s i$ & 1 & 1.00 & 451 & 28 & 14 & 7 & 29 & 15 & 25 & 28 & 24 & 20 & 19 & 33 & 25 & 22 & & & & & & \\
\hline$X$. populi & 75 & 0.69 & 413 & 25 & 19 & 16 & 18 & 21 & 22 & 23 & 20 & 16 & 20 & 28 & 20 & 14 & 28 & & & & & \\
\hline$X$ sacchari & 6 & 0.94 & 541 & 33 & 25 & 17 & 32 & 24 & 30 & 29 & 27 & 27 & 26 & 34 & 29 & 29 & 35 & 36 & & & & \\
\hline$X$. theicola & 3 & 0.97 & 510 & 31 & 22 & 19 & 31 & 23 & 28 & 32 & 26 & 21 & 25 & 27 & 29 & 28 & 33 & 29 & 29 & & & \\
\hline$X$. translucens & 92 & 0.67 & 246 & 17 & 7 & 2 & 12 & 7 & 12 & 15 & 8 & 9 & 6 & 21 & 11 & 12 & 19 & 20 & 20 & 24 & & \\
\hline$X$. vasicola & 20 & 0.82 & 303 & 17 & 13 & 6 & 13 & 11 & 12 & 20 & 15 & 14 & 12 & 26 & 13 & 8 & 24 & 18 & 30 & 26 & 15 & \\
\hline$X$. vesicatoria & 7 & 0.90 & 281 & 17 & 7 & 2 & 16 & 1 & 14 & 13 & 13 & 16 & 8 & 26 & 17 & 13 & 23 & 20 & 29 & 27 & 9 & 10 \\
\hline
\end{tabular}

"Sum of the values in the matrix.

the descriptions of species in terms of average fatty acid contents provided in this paper are a substantial step forward in the description of Xanthomonas species and rapid identification of these taxa. It is very important that bacterial taxa be defined on the basis of large numbers of strains obtained from a broad geographic area and diverse ecological habitats. However, when this is done, absolute discriminative features become difficult to find or may be unavailable, and a statistical approach should be used to describe the organisms. These criteria were fulfilled in this study, which was for the most part an extension of the work performed by Yang et al. (26) in view of the current classification of the genus Xanthomonas and the need for phenotypic descriptions of Xanthomonas species.

\section{ACKNOWLEDGMENTS}

L.V. is indebted to the Nationaal Fonds voor Wetenschappelijk Onderzoek for a scholarship. We acknowledge the Algemeen Bestuur voor Ontwikkelingssamenwerking for scholarships and research grants. Part of this work was carried out in the framework of Microbial Diversity Network contract ERBCHRXCT930194.

\section{REFERENCES}

1. Abel, K., H. De Schmertzing, and J. I. Peterson. 1963. Classification of microorganisms by analysis of chemical composition. J. Bacteriol. 85:10391044.

2. Collins, M. D., M. Goodfellow, and D. E. Minnikin. 1982. A survey of the structures of mycolic acids in Conyebacterium and related taxa. J. Gen. Microbiol. 128:129-149.

3. Collins, M. D., M. Goodfellow, and D. E. Minnikin. 1982. Fatty acid composition of some mycolic acid-containing coryneform and related bacteria. J. Gen. Microbiol. 128:2503-2509.

4. Collins, M. D., M. Goodfellow, and D. E. Minnikin. 1982. Polar lipid composition in the classification of Arthrobacter and Microbacterium. FEMS Microbiol. Lett. 15:299-302.

5. De Boer, S. H., and M. Sasser. 1986. Differentiation of Enwinia carotovora spp. carotovora and E. carotovora spp. atroseptica on the basis of cellular fatty acid composition. Can. J. Microbiol. 32:796-800.

6. Gitaitis, R. D., and R. W. Beaver. 1990. Characterization of fatty acid methyl ester content of Clavibacter michiganensis subsp. michiganensis. Phytopathology 80:318-321.
7. Graham, J. H., J. S. Hartung, R. E. Stall, and A. R. Chase. 1990. Pathological, restriction-fragment length polymorphism, and fatty acid profile relationships between Xanthomonas campestris from citrus and noncitrus hosts. Phytopathology 80:829-836.

8. Hartung, J. S., and E. L. Civerolo. 1987. Genomic fingerprints of Xanthomonas campestris pv. citri strains from Asia, South America, and Florida. Phytopathology 77:282-285.

9. Henningson, P. J., and N. C. Gudmestad. 1991. Fatty acid analysis of phytopathogenic coryneform bacteria. J. Gen. Microbiol. 137:427-440.

10. Janse, J. D. 1991. Pathovar discrimination within Pseudomonas syringae subsp. savastanoi using whole cell fatty acids and pathogenicity as criteria. Syst. Appl. Microbiol. 14:79-84.

11. Janse, J. D. 1991. Infra- and intraspecific classification of Pseudomonas solanacearum strains, using whole cell fatty acids analysis. Syst. Appl. Microbiol. 14:335-345.

12. Korn-Wendisch, F., A. Kempf, E. Grund, R. M. Kroppenstedt, and H. J. Kutzner. 1989. Transfer of Faenia rectivirgula Kurup and Agre 1983 to the genus Saccharopolyspora Lacey and Goodfellow 1975, elevation of Saccharopolyspora hirsuta subsp. taberi Labeda 1987 to species level, and emended description of the genus Saccharopolyspora. Int. J. Syst. Bacteriol. 39:430441.

13. Miller, L. T. 1982. Single derivatization method for routine analysis of bacterial whole-cell fatty acid methyl esters, including hydroxy acids. J. Clin. Microbiol. 16:584-586.

14. Roy, M. A. 1988. Use of fatty acids for the identification of phytopathogenic bacteria. Plant Dis. 72:460.

15. Sasser, J. M., D. J. Fieldhouse, and C. N. Carter. 1984. Computer assisted identification of bacteria based on fatty acid analysis. Phytopathology 74: 882.

16. Stead, D. E. 1989. Grouping of Xanthomonas campestris pathovars of cereals and grasses by fatty acid profiling. Bull. OEPP (Organ. Eur. Mediterr. Prot. Plant.)/EPPO (Eur. Mediterr. Plant. Prot. Organ.) Bull. 19:57-68.

17. Stead, D. E. 1992. Grouping of plant-pathogenic and some other Pseudomonas spp. by using cellular fatty acid profiles. Int. J. Syst. Bacteriol. 42: $281-295$.

18. Stead, D. E., J. E. Sellwood, J. Wilson, and I. Vieny. 1992. Evaluation of a commercial microbial identification system based on fatty acid profiles for rapid, accurate identification of plant pathogenic bacteria. J. Appl. Microbiol. 72:315-321.

19. Suzuki, K., M. Goodfellow, and A. G. O'Donnell. 1993. Cell envelopes and classification, p. 195-250. In M. Goodfellow and A. G. O'Donnell (ed.), Handbook of new bacterial systematics. Academic Press, London.

20. Vauterin, L., B. Hoste, K. Kersters, and J. Swings. 1995. Reclassification of Xanthomonas. Int. J. Syst. Bacteriol. 45:472-489.

21. Vauterin, L., J. Swings, and K. Kersters. 1991. Grouping of Xanthomonas 
campestris pathovars by SDS-PAGE of proteins. J. Gen. Microbiol. 137: $1677-1687$.

22. Vauterin, L., J. Swings, K. Kersters, M. Gillis, T. W. Mew, M. N. Schroth, N. J. Palleroni, D. C. Hildebrand, D. E. Stead, E. L. Civerolo, A. C. Hayward, H. Maraite, R. E. Stall, A. K. Yidaver, and J. F. Bradbury. 1990. Towards an improved taxonomy of Xanthomonas. Int. J. Syst. Bacteriol. 40:312-316.

23. Vauterin, L., P. Yang, B. Hoste, B. Pot, J. Swings, and K. Kersters. 1992. Taxonomy of xanthomonads from cereals and grasses based on SDS-PAGE of proteins, fatty acid analysis and DNA hybridization. J. Gen. Microbiol. 138: $1467-1477$
24. Vauterin, L., P. Yang, B. Hoste, M. Vancanneyt, E. L. Civerolo, J. Swings, and K. Kersters. 1991. Differentiation of Xanthomonas campestris pv. citri strains by sodium dodecyl sulfate-polyacrylamide gel electrophoresis of proteins, fatty acid analysis, and DNA hybridization. Int. J. Syst. Bacteriol. 41: $535-542$.

25. Welch, D. F. 1991. Application of cellular fatty acid analysis. Clin. Microbiol. Rev. 4:422-438.

26. Yang, P., L. Vauterin, M. Vancanneyt, J. Swings, and K. Kersters. 1993. Application of fatty acid methyl esters for the taxonomic analysis of the genus Xanthomonas. Syst. Appl. Microbiol. 16:47-71. 